\title{
REPRESENTASI NILAI RELIGI DAN KEPENGARANGAN PUISI-PUISI KARYA TAUFIK ISMAIL
}

\author{
Emil Septia ${ }^{1}$, Silvia Marni ${ }^{2}$, Armet $^{3}$ \\ Program Studi Pendidikan Bahasa dan Sastra Indonesia \\ STKIP PGRI Sumatera Barat \\ Jl.Gunung Pangilun,Sumatera Barat,Indonesia \\ emil_paradise@yahoo.co.id/emil@stkip-pgri-sumbar.ac.id ${ }^{1}$, \\ silviamarnindo@gamil.com², armetpgri@gmail.com ${ }^{3}$
}

\begin{abstract}
Abstrak
Penelitian ini memaparkan representasi nilai religi dalam setiap bait-bait puisi karya Taufik Ismail. Puisi yang bernilai religius dapat digunakan untuk menyadarkan masyarakat (pembaca) untuk selalu bersyukur pada Tuhan Sang Penguasa. Kumpulan puisi Debu di Atas Debu: Kumpulan Puisi Dwi-Bahasa karya Taufik Ismail merupakan catatan-catatan emosional zaman dengan gejolak politik dan sikap bangsa Indonesia. Jenis penelitian ini berupa kualitatif dengan metode analisis isi (content analysis) serta pendekatan sosiologi sastra. Hal ini bertujuan untuk mendeskripsikan kepengarangan Taufik yang terdapat pada representasi nilai religi di setiap bait-bait puisi. Melalui seni pedalangan ketika Taufik bermukim di Yogyakarta dan seni bakaba ketika Taufik pindah ke Bukittinggi yang merupakan bentuk gaya kepengaranan seorang penyair yang dipengaruhi kebudayaan lokal, Taufik ingin menyentuh perasaan pembaca akan representasi nilai religius untuk membentuk karakter bangsa.
\end{abstract}

Kata Kunci: representasi; nilai; religi; kepengarangan; puisi

\begin{abstract}
This study describes the representation of religious values in each poetic verse by Taufik Ismail. Religious poetry can be used to make people (readers) aware to always be grateful to God the Lord. A collection of Debu di Atas Debu: Kumpulan Puisi DwiBahasa by Taufik Ismail is an emotional record of the times with political turmoil and the attitude of the Indonesian people. This type of research is qualitative with the method of content analysis and the sociological approach of literature. This is aimed at describing Taufik's authorship in the representation of religious values in each verse of poetry. Through the art of puppetry when Taufik settled in Yogyakarta and bakaba art when Taufik moved to Bukittinggi which was a form of the poet's sound style influenced by local culture, Taufik wanted to touch the readers' feelings about the representation of religious values to shape the nation's character.
\end{abstract}

Keywords: representation; values; religion; authorship; poetry

\section{Pendahuluan}

Puisi yang bergenre religius yang Puisi yang bersifat religius memiliki diciptakan oleh penyair merupakan genre hubungan yang erat dengan filsafat dan yang penting. Puisi yang bernilai religius agama. Senada tersebut, Aminudin dapat digunakan untuk menyadarkan (2011:197) menyatakan bahwa sebagai hasil masyarakat (pembaca) untuk selalu kreasi manusia puisi mampu memaparkan bersyukur dan kembali kejalan yang benar. realitas di luar dirinya. Puisi adalah semacam 
cerminan yang menjadi representasi dari realitas itu sendiri. Tegasnya puisi akan mengandung empat masalah yang berhubungan dengan (1) kehidupan, (2) kematian, (3) kemanusiaan, (4) ketuhanan.

Pada hakikatnya kehidupan manusia kompleks dengan berbagai masalah kehidupan. Dalam kehidupan yang kompleks tersebut terdapat beberapa permasalahan kehidupan yang mencakup hubungan antarmasyarakat, antarmanusia, manusia dengan Tuhannya, dan antarperistiwa yang terjadi dalam batin seseorang. Seorang pengarang yang peka terhadap permasalahan -permasalahan tersebut dengan hasil perenungan, penghayatan, dan hasil imajinasinya, kemudian menuangkan gagasan atau idenya tersebut dalam karya sastra. Sebagai media ekspresi karya sastra, bahasa sastra dimanfaatkan oleh sastrawan guna menciptakan efek makna tertentu guna mencapai efek estetik. Bahasa sastra sebagai media ekspresi sastrawan digunakan untuk mencapai efek estetis, dalam hal ini berhubungan dengan style 'gaya bahasa' sebagai sarana sastra. Dengan demikian, plastisitas dan estetika bahasa menjadi penting dalam karya sastra.

Untuk mencapai efektivitas pengungkapan, bahasa sastra disiasati, dimanipulasi, dieksploitasi, dan diberdayakan seoptimal mungkin sehingga tampil dengan bentuk yang plastis, yang berbeda dengan bahasa nonsastra. Oleh karena itu, karya sastra di samping disebut dunia dalam imajinasi, juga disebut dunia dalam kata. Dunia yang diciptakan, dibangun, ditawarkan, dan diabstraksikan dengan kata, dengan bahasa. Berbagai genre sastra dapat dibaca oleh pembaca sebagai bahan renungan dan sebagai hiburan, yaitu: prosa, puisi, dan drama. Dari tiga genre karya sastra tersebut, puisi merupakan genre sastra yang sarat akan makna nilai-nilai yang diciptakan penyair untuk pencerahan dan pembelajaran bagi pembacanya.

Di antara berbagai puisi yang kental mengenai religius dapat dilihat pada puisi Perjalanan Menujumu karya Isbedy Stiawan, puisi Sembahyang Rumputan karya Ahmadun Yosi Herfanda, puisi Tadarus (Antologi Puisi) karya A Mustofa Bisri,dan puisi Tuhan, Kita Begitu Dekat karya Abdul Hadi MW. Deretan penyair di atas banyak menciptakan karya yang bergenre religius. Penyair-penyair tersebut adalah penyair-penyair muda yang menghasilkan karya-karya puisi yang berkualitas. Walaupun penyair-penyair muda tersebut banyak bermunculan, penyair senior juga tidak kalah pamornya, yaitu Taufik Ismail. Taufik Ismail tetap matang dalam menciptakan karya puisi, bahkan di usianya yang sudah mencapai 80 tahun. Ia tetap eksis sebagai penyair yang produktif hingga saat ini. Senada dengan Faridoni (2013) Taufik Ismail juga memiliki kedalaman dimensi ketuhanan dan dimensi kemanusiaan. Hal ini dapat dinamakan sebagai puisi yang transendental atau yang lebih dikenal dengan puisi profetik. Tidak heran jika Kuntowijoyo dan Sayuti menyebut 
Taufik sebagai "penyair yang menghayati sejarah".

Taufik lahir di Bukittinggi 25 Juni 1935 merupakan penyair terkemuka di Indonesia. Puisi Taufik Ismail dalam perkembangan sastra modern di Indonesia mengalami perubahan sesuai dengan perkembangan dunia sastra saat ini. Taufik Ismail hidup pada masa orde lama angkatan 1966. Pada masa itu, karyanya banyak mengangkat protes terhadap ketidakadilan dan penyelewengan yang terjadi di masyarakat. Beliau memotret berbagai peristiwa berdarah pada terjadinya demonstrasi besarbesaran terhadap pemerintah pada masa itu. Hal ini terlihat pada karya puisinya yang berjudul Tirani dan Benteng. Keunikan yang dirasakan pembaca ketika menikmati karyanya, Taufik mampu mengemas pesan kepada pembaca dengan makna yang terdapat dalam puisinya. Seolah-olah pembaca tersentuh atas saran yang dituliskan dalam puisinya.

Karya Taufik Ismail yang kental dengan unsur religius adalah kumpulan puisi yang berjudul Debu di Atas Debu: Kumpulan Puisi Dwi-Bahasa. Kumpulan puisi ini bisa memberikan inspirasi yang kuat bagi peningkatan rohani menuju perbuatan yang lebih baik. Kumpulan puisi ini sangat berkarakter dan menggugah, serta memberikan inspirasi bagi kemuliaan hidup di dunia dan akhirat. Puisi ini terbit dalam dua bahasa yaitu bahasa Arab dan bahasa Indonesia. Unsur gaya bahasa dalam puisi
Taufik Ismail yang terdapat pada karyanya menjadikan puisi tersebut menjadi puitis, indah, dan menarik. Pembinaan dan pengembangan sastra khususnya puisi sebagai bagian kebudayaan nasional perlu dilaksanakan karena di dalam puisi terkandung nilai-nilai yang penting bagi bangsa Indonesia. Pada era digital diketahui generasi bangsa Indonesia dewasa ini sangat memprihatinkan karena kemerosotan nilai pendidikan, khususnya nilai religi pada seseorang mengakibatkan rusaknya tatanan dan peradaban kehidupan bangsa, baik kehidupan orang dewasa, maupun generasi muda. Kumpulan puisi Debu di Atas Debu: Kumpulan Puisi Dwi-Bahasa karya Taufik Ismail merupakan catatan-catatan emosional zaman dengan gejolak politik dan sikap bangsa Indonesia. Berdasarkan kenyataan itu, dilakukan penelitian representasi nilai religi dan kepengarangan puisi-puisi karya Taufik Ismail. Representasi merupakan konsep yang menghubungkan antara makna dan bahasa. Representasi juga dapat berarti menggunakan bahasa untuk mengatakan sesuatu yang penuh arti atau menggambarkan dunia yang penuh arti kepada orang lain. Selain itu, representasi merupakan sebuah bagian esensial dari proses ketika makna dihasilkan dan diubah oleh anggota kultur tersebut.

Representasi adalah jalan ketika makna diberikan kepada hal-hal yang tergambar melalui citra atau bentuk lainnya pada layar atau pada kata-kata. Hall mengungkapkan representasi harus dipahami 
dari peran aktif dan kreatif orang memaknai dunia. Hall juga menambahkan bahwa sebuah citra akan mempunyai makna yang berbeda dan tidak ada garansi bahwa citra akan berfungsi atau bekerja sebagaimana mereka dikreasi atau dicipta. Representasi adalah peristiwa kebahasaan. Bagaimana seseorang ditampilan dapat dijelaskan dengan menggunakan sebuah bahasa. Melalui bahasalah berbagai tindakan representasi tersebut ditampilkan oleh media dan dihadirkan dalam pemberitaan. oleh karena itu, yang patut dikritisi ialah pemakaian bahasa yang ditampilkan oleh media. Proses ini mau tidak mau sangat berhubungan dengan pemakaian bahasa dalam menuliskan realitas untuk dibaca khalayak. Representasi (Sugono, dkk., 2008:1167) adalah perbuatan mewakili, keadaan diwakili, apa yang mewakili, perwakilan.

Penelitian kumpulan puisi Debu di Atas Debu: Kumpulan Puisi Dwi-Bahasa karya Taufik Ismail pernah dilakukan oleh peneliti lain, yaitu Azami dengan judul penelitian "Penerjemahan sebagai Penafsiran: Studi Akurasi dan Gaya Bahasa Puisi Taufik Ismail Debu di Atas Debu". Kedua, Putri dengan judul penelitian "Gaya Bahasa Perulangan dalam Kumpulan Puisi Debu di Atas Debu Karya Taufik Ismail". Kedua penelitian terdahulu tersebut berbeda dengan penelitian yang dilakukan ini, yaitu penelitian ini memfokuskan tentang representasi nilai religi dan pengaruh kebudayaan lokal kepengarangan puisi karya Taufik Ismail.
Oleh karena itu, rumusan penelitian ini menitikberatkan pada kajian tentang "Bagaimanakah representasi nilai religi dan kepengarangan puisi-puisi karya Taufik Ismail?"

Penelitian ini adalah penelitian kualitatif karena data penelitian berupa teks atau katakata. Ratna (2010:47), menyatakan jenis kualitatif memberikan perhatian terhadap data ilmiah, data dalam hubungannya dengan konteks keberadaannya. Cara-cara inilah yang mendorong metode kualitatif dianggap sebagai multimetode, sebab penelitian pada gilirannya melibatkan sejumlah besar gejala sosial yang relevan. Penelitian karya sastra, misalnya, akan dilibatkan pengarang, lingkungan sosial tempat pengarang berada, termasuk unsur-unsur kebudayaan pada umumnya. Metode yang digunakan dalam penelitian ini adalah analisis isi (content analysis). In content analysis, indices of unobservable or only indirectly accessible phenomena are most common (Krippendorff, 2004). Ratna (2010:48-49), menguraikan metode analisis isi terdiri atas dua macam, yaitu isi laten dan isi komunikasi. Isi laten adalah isi yang terkandung dalam dokumen dan naskah, sedangkan isi komunikasi adalah pesan yang terkandung sebagai akibat komunikasi yang terjadi. Jadi analisis isi laten menghasilkan arti, sedangkan analisis terhadap isi komunikasi menghasilkan makna. Oleh karena itu, metode analisis isi dilakukan dalam dokumen-dokumen yang padat isi. Penelitian menekankan bagaimana memaknai isi komunikasi, menekankan isi 
interaksi simbolik yang terjadi dalam peristiwa komunikasi. Penggunaan metode analisis isi pada penelitian ini adalah untuk menggambarkan atau mendeskripsikan data mengenai nilai religi dan pengaruh kebudayaan lokal dalam kepangarangan kumpulan puisi Taufik Ismail.

Data penelitian adalah larik-larik puisi yang berkaitan dengan representasi nilai religi. Sementara itu, sumber data penelitian ini adalah kumpulan puisi Debu di Atas Debu: Kumpulan Puisi Dwi-Bahasa karya Taufik Ismail terbit tahun 2013. Dalam kumpulan puisi ini terdiri dari 111 puisi yang terbagi menjadi lima bagian. Bagian pertama terdiri dari 40 judul puisi, bagian kedua terdiri dari 36 judul puisi, bagian ketiga terdiri dari 8 judul puisi, bagian keempat terdiri dari 19 judul puisi, bagian kelima terdiri dari 8 judul puisi.

Selain menggunakan metode analisis isi, penelitian ini juga menggunakan pendekatan sosiologi sastra. Secara umum, sosiologi sastra mempelajari hubungan timbal balik antarunsur sosial sastra, yaitu karya, pengarang, realitas, pembaca, dan distribusi karya. Secara khusus, sosiologi sastra mempelajari hubungan realitas dunia dengan realitas fiksi dalam karya (Mahmud, 2011:2). Dalam kesempatan kali ini, penulis memfokuskan penelitian pada hubungan antara karya, pengarang, dan realitas yang ada.

Hal ini berkaitan karena sosiologi sastra tidak hanya memfokuskan penelitian pada teks sebagai benda budaya yang otonom, sumber-sumber yang di luar teks sastra itu pun merupakan bahan penting. Pengetahuan mengenai sejarah, situasi sosial, dan politik, perkembangan media, agama, struktur sosial, nilai-nilai dan norma-norma yang berlaku di masyarakat, proses reproduksi sastra, riwayat hidup pengarang, dan lain-lain merupakan sumber yang sangat berharga (Endraswara, 2011a:104).

Di antara kebutuhan manusia, baik secara individu maupun kelompok, adalah sandaran spiritualitas. Manusia membutuhkan dogma agama dalam menjalani kehidupan, baik secara individu maupun kelompok. Pada konteks kebudayaan, dogma agama menjadi penting. Karena agama memiliki kapasitas untuk membangun konsepsi pada pikiran dan psikologi manusia. Agama beserta konsepkonsep ajarannya memberikan kerangka gagasan pemaknaan terkait banyak hal dalam kehidupan manusia (Geertz, 2000:123). Oleh karena itu, agama memengaruhi terbentuknya sistem kebudayaan pada masyarakat. Agama mengisi ruang-ruang nilai, moralitas, etika, estetika dan banyak lagi dari kebudayaan. Hadirnya agama Islam di Indonesia ini menarik karena secara kultural memberi-kan warna terhadap kebudayaan di Indone-sia yang telah lebih dahulu dipengaruhi oleh agama Buddha dan Hindu. Islam memberikan dampak kepada persilangan nilai-nilai budaya di Indonesia.

Islam ditinjau dari ajarannya sesungguhnya mengatur hubungan tiga hal: (1) bagaimana 
cara berhubungan dengan Allah (HablunminAllah) sebagaimana firman Allah SWT, "Dan Aku tidak menciptakan jin dan manusia melainkan supaya mereka menyembahku," (surat Adz-Dzariyat ayat 56). (2) bagaimana cara berhubungan dengan sesama manusia (Hablunminan-Nas) sebagaimana firman Allah SWT., "Dan tolong-menolonglah kamu dalam (mengerjakan) kebajikan dan takwa, dan janganlah tolong-menolong dalam berbuat dosa dan permusuhan" (surat AlMaidah ayat 2). (3) bagaimana cara berhubungan dengan makhluk lainnya (lingkungan). Jadi, ajaran Islam mencakup tiga aspek yang mendasar sebagai kewajiban dan tujuan hidup manusia di dunia. Ketiga aspek itu adalah akidah, akhlak, dan ibadah. Dalam hal ini, ketiga aspek tersebut akan dijadikan landasan berpikir untuk mengklasifikasikan nilai-nilai Islam dalam kumpulan puisi karya Taufik Ismail. Adapun ketiga aspek tersebut dapat diuraikan sebagai berikut. Akidah merupakan komponen pokok dalam agama Islam.

Akidah atau iman merupakan keyakinan akan adanya Allah dan para rasul yang diutus dan dipilih-Nya untuk menyampaikan risalah -Nya kepada umat melalui malaikat yang dituangkan dalam kitab suci-Nya yang berisikan informasi tentang adanya hari akhirat dan adanya suatu kehidupan sesudah mati serta informasi tentang segala sesuatu yang telah direncanakan dan ditentukan Allah (Nurdin, 1995:37).

Akhlak seseorang merupakan buah dan hasil didikan ibadah pokok sedang akan ibadah itu sendiri adalah pancaran keluar dari iman. Maka akhlak manusia yang baik itu adalah hasil daripada ibadah kepada Tuhan karena tidak mungkin ada akhlak yang bertakwa tanpa ibadah. Menurut Razak (dalam Nurbanah, 2003:21) akhlak adalah perbuatan suci yang terbit dari lubuk jiwa yang paling dalam karenanya mempunyai kekuatan yang hebat. Sementara itu, menurut Al-Ghazaly (dalam Nurbanah, 2003:21) akhlak adalah sifat yang tertanam dalam jiwa daripadanya timbul perbuatan yang mudah tanpa memerlukan pertimbangan pikiran.

Ibadah merupakan kegiatan manusia, baik yang bersifat ubudiyah maupun yang bersifat muamalah adalah dikerjakan dalam rangka penyembahan kepada Allah dan mencari keridaan-Nya. Suatu pekerjaan bernilai ibadah atau tidak tergantung kepada niatnya dan Islam menuntut agar kehidupan manusia itu harmonis dan seimbang, baik hubungannya dengan Tuhan maupun alam sekitarnya. Suryana, dkk. (1996:82-83) ibadah adalah perhambaan seorang manusia kepada Allah sebagai pelaksanaan tugas hidup selaku makhluk yang diciptakan Allah. Ibadah ada dua macam, yaitu ibadah khusus atau ibadah mahdhah dan ibadah umum atau ibadah ghairumahdhah. Ibadah khusus adalah ibadah langsung kepada Allah yang telah ditentukan macamnya, tata cara, dan syarat rukunnya telah diatur oleh Allah dalam Alquran dan melalui sunah rasul dalam haditsnya. Pelanggaran terhadap tatacara dan syarat 
rukun dalam ibadah ini menjadikan ibadah tersebut tidak sah atau batal.

\section{Permasalahan}

Nilai-nilai Islam dalam kumpulan puisi Debu di Atas Debu: Kumpulan Puisi DwiBahasa Karya Taufik Ismail ini diklasifikasikan menjadi tiga unsur pokok dalam struktur agama Islam, yaitu akidah, ibadah, dan akhlak. Ketiga unsur ini pada dasarnya merupakan satu kesatuan dalam ajaran Islam. Ketiga unsur tersebut dapat dibedakan, tetapi tidak bisa dipisahkan. Akidah sebagai sistem kepercayaan yang bermuatan elemen-elemen dasar keyakinan, menggambarkan sumber, dan hakikat keberadaan agama. Sementara ibadah sebagai kewajiban dan tujuan hidup dari perputaran roda sejarah manusia di dunia. Sementara itu, akhlak sebagai sistem etika menggambarkan arah dan tujuan yang hendak dicapai agama. Oleh karena itu, ketiga unsur tersebut seyogyanya terintegrasi dalam diri seorang Muslim.

Nilai-nilai Islam yang terdapat dalam kumpulan puisi Debu di Atas Debu: Kumpulan Puisi Dwi-Bahasa karya Taufik Ismail terungkap melalui penataan bunyi, pilihan kata, penggunaan gaya bahasa, pencitraan, latar belakang realitas pemerintahan orde baru, sikap penyair terhadap realitas yang ditampilkan, dan sikap penyair terhadap pembaca. Adapun akidah yang terdapat dalam kumpulan puisi Debu di Atas Debu: Kumpulan Puisi Dwi-Bahasa Karya Taufik
Ismail meliputi iman kepada Allah, iman kepada Malaikat, iman kepada Rasul, iman kepada Takdir, iman kepada Hari Kiamat. Ibadah yang terkandung dalam kumpulan puisi ialah bermunajat, berdakwah, berdoa. Sementara itu, akhlak dalam kumpulan puisi meliputi akhlak baik (mahmudah) yakni tidak berputus asa, berbakti pada orang tua, bertaubat, berpendirian, sedangkan akhlak buruk (mazmumah) meliputi zalim. Berikut uraian representasi nilai religi dalam kumpulan puisi Debu di Atas Debu: Kumpulan Puisi DwiBahasa karya Taufik Ismail.

\section{Akidah}

Akidah merupakan keyakinan dan kepercayaan mengenai sebuah kebenaran berdasarkan akal, wahyu dan fitrah yang telah tertanam dengan kokoh dan kuat di dalam hati yang dapat menentramkan jiwa tanpa ada keraguan sedikitpun. Berikut jabaran tentang akidah yang terdapat dalam kumpulan puisi karya Taufik Ismail.

\section{a. Iman Kepada Allah SWT.}

Iman kepada Allah SWT adalah percaya dan meyakini dengan sepenuh hati terhadap sifatsifat Allah dan adanya iman kepada Allah pada diri seseorang dibuktikan dengan perbuatannya sebagai dampak dari keyakinan itu. Beriman kepada Allah merupakan keimanan yang paling pokok dan mendasar. Jika manusia telah beriman bahwa Allah itu ada, maka dalam perilaku manusia akan lahir sikap hati-hati dan waspada. Manusia tidak akan merasa sendirian, kendati tidak ada 
orang lain di sekitarnya, sebab ia yakin bahwa Allah itu ada. Selama iman itu ada dalam diri manusia, manusia tidak akan dapat berbuat hal yang melanggar perintah Allah SWT.

Penggambaran iman kepada Allah SWT. ini dapat dilihat pada puisi berjudul "Cerita Seorang Anak Yatim Piatu Selepas Pesta Ulang Tahun Tetangganya" dalam bait berikut.

Katanya: 'kok tiupan nyala 16 lilin bisa menentukan nasib saya?

\section{Allah menentukan nasib saya}

Sesudah kerja keras saya

\section{(Ismail, 2014:103)}

Kutipan bait puisi di atas menjelaskan pemaknaan akidah iman kepada Allah SWT. Hal ini ditandai dengan bait yang dihitamkan bermakna penyair menyampaikan pemaknaan seorang anak kecil yang baru saja merayakan ulang tahun meyakini bahwa yang menentukan umur dan nasibnya adalah Allah SWT yang sudah menciptakannya, bukan jumlah lilin pada kue atau pada setiap tanggal kelahirannya diperingati. Penggalan bait puisi tersebut mengajak pembaca untuk mensyukuri nikmat serta meyakini bahwa Allah SWT adalah Tuhan yang Maha Penyayang lagi penentu nikmat yang terbaik untuk umatnya. Selain, makna iman/keyakinan bahwa adanya Allah SWT., puisi tersebut juga menyampaikan pesan secara tersirat oleh penyair bahwa sebagai umat ciptaan
Tuhan harus selalu berusaha rajin baik dalam belajar, beribadah, dan bekerja serta bersyukur untuk menjadi seseorang yang bertakwa.

Selain itu iman kepada Allah SWT juga diungkapkan oleh Taufik Ismail pada puisi berjudul "Rindu Kami Pada Ketenangan, Rindu Kami Pada Kedamaian" yaitu dalam bait beikut.

\section{Kemudia kami berdoa kepada Tuhan}

\section{Rabbana ya Allah yaTuhan}

(Ismail, 2013:197)

Penggalan bait di atas mendeskripsikan pemaknaan akidah iman kepada Allah SWT. Hal ini ditandai dengan adanya kutipan doa yang dilantunkan kepada Allah SWT. Sang pencipta dan penguasa langit serta isinya. Walaupun dalam keadaan susah ikhtiar dan doa bergema pada bait puisi tersebut. Dalam keadaan kisruh politik dan ekonomi serta bencana alam pada masa pemerintahan orde baru, penyair mengharapkan adanya perdamaian dan keadilan untuk semua umat terutama untuk anak-anak yang sudah tidak memiliki kedua orang tua serta tempat tinggal. Oleh sebab itu, melalui bait-bait puisi yang ditulis oleh penyair sarat akan representasi nilai Islam yang patut diteladani bagi siapa pun.

Iman kepada Allah SWT. juga diungkapkan oleh Taufik Ismail pada puisi berjudul "Zikir Yang Tiada Putus-putusnya".

Laut dan gunung bertasbih memuja Tuhan Awan dan sungai berzikir mengagungkan 
Poetika : Jurnal Ilmu Sastra

Vol. VII No. 1, Juli 2019

\section{Tuhan}

Pohon-pohon bertasbih memuja Tuhan

Rabban ikutkan kami berzikir bersama mereka

(Ismail, 2013:329)

Kutipan bait di atas menjelaskan akidah iman kepada Allah SWT. Hal ini ditandai dengan adanya kutipan doa yang dituliskan bermakna bahwa sang penyair ingin disertakan bersama alam semesta dan malaikat berzikir memuja Allah dengan khusyuk. Dalam keadaan apa pun, penyair mengajak pembaca untuk selalu mengingat Allah SWT. dengan cara melantunkan zikir dengan suara yang merdu. Di antara ciri orang yang keimanannya selalu meningkat ialah apabila mereka diingatkan dan dibacakan ayat-ayat Allah, baik ayat kauniyah (ciptaan Allah) maupun ayat qauliah (firman Allah) yang menunjukkan kebesaran dan keagungan Allah, maka hatinya bergetar dan semakin kuat imannya. Hal tersebut sesuai interpretasi dalam Alquraan, berbunyi “Sesungguhnya orang-orang yang beriman itu adalah mereka yang apabila disebut (asma) Allah bergetarlah hati mereka, dan apabila dibacakan kepada mereka ayat- ayatNya, bertambahlah iman mereka" (Q.S. AlAnfal:2).

\section{b. Iman Kepada Rasul Allah}

Rasul adalah manusia yang dipilih Allah dan diberi kuasa untuk menerangkan segala sesuatu yang datang dari Allah. Beriman kepada rasul merupakan tuntutan iman kepada Allah, dan Allah menyuruhnya untuk mengimaninya. Iman kepada Rasul Allah dapat dilihat pada puisi berjudul "Anakku Bertanya Tentang Rasul"dalam bait berikut.

\section{Anakku bertanya padaku \\ Mengapa Rasul itu mulia? \\ Rasul Mulia, hai anakku \\ Karena dia sederhana.}

(Ismail, 2013:455)

Penggalan bait puisi di atas bermakna akidah iman kepada Rasul Allah, yaitu Nabi Muhammad Saw. Seorang (tokoh ibu) meyakini bahwa Rasul adalah nabi yang mulia pilihan Allah SWT. Hal ini dijelaskan dengan rinci kepada anaknya ketika sang anak bertanya pada seorang ibu tersebut. Dengan penuh kelembutan tokoh Ibu tersebut menjelaskan kepada anaknya agar anaknya juga meyakini bahwa Rasul adalah nabi utusan Allah SWT. yang paling mulia dan penuh kesederhaan. Sifat sederhana Rasul hendaknya ditiru oleh siapa pun.

Selain itu iman kepada Rasul juga terdapat pada puisi berjudul "Rasul Menyuruh Kita"

Kita cintai orang-orang lapar dan berkekurangan

Kita cintai orang-orang tertindas, dimanapun mereka

Kita cintai anak yatim dan piatu

Pada Rasulullah kita bersangatan cinta

Gemetar kami dalam zikir

Gagap kami menyanyikan shalawat

Tiada cukup butir tasbih

Tiada memada kosa kata

Dalam membalas cintanya

Secara sederhana.

(Ismail, 2013:273-275) 
Kutipan bait puisi tersebut menjelaskan akidah iman kepada Rasul. Hal ini ditandai dengan/pada Rasulullah kita bersangatan cinta/... / gagap kami menyanyikan shalawat/ yang bermakna keyakinan kepada Rasul dalam menyayangi dan menyantuni anak yatim dan piatu serta orang-orang yang kekurangan harta maupun pendidikan selayaknya yang pernah dilakukan oleh Rasul. Serta melantunkan salawat untuk Rasul.

\section{c. Iman Kepada Malaikat Allah}

Allah menciptakan malaikat, yaitu makhluk gaib yang melaksanakan tugastugas yang diberikan Allah. Ia diciptakan Allah dari cahaya. Seorang muslim wajib mengimani adanya malaikat sebagai makhluk Allah di samping manusia, jin dan iblis. Keyakinan terhadap adanya malaikat, bukan hanya sebatas mengetahui nama dan tugas malaikat, melainkan melahirkan dampaknya pada perilaku. Setiap manusia akan selalu berhati-hati, sebab apapun perbuatannya akan dicatat oleh malaikat dan diminta pertanggung-jawabannya. Penggambaran keimanan atau keyakinan terhadap malaikat dapat dilihat pada puisi yang berjudul "Ternyata Kau Shalat Tidak Sendirian" yaitu dalam bait berikut.

Ketika azan dikumandangkan

Ketika iqmat diserukan

Lalu shalat ditegakkan

Shaf malaikat dari timur ke barat memanjang

Bila qiblat di barat di letaknya

Shaf malaikat dari membentang dari utara ke selatan

(Ismail, 2013:343)

Penggalan bait puisi di atas bermakna akidah iman kepada malaikat. Penyair menjelaskan kepada pembaca bahwa ketika seseorang melaksanakan salat dia tidak sendirian walaupun sesorang tersebut melaksanakan salat sendirian karena ada malaikat yang selalu setia menemani dari penjuru arah mana pun. Begitulah tugas malaikat yang diperintahkan oleh Allah SWT. Hal ini juga diterangkan oleh Allah SWT. Lewat kitab suci Alquran yang diwahyukan kepada Nabi Muhammad SAW lewat perantara malaikat Jibril.

\section{d. Iman Kepada Kitab Suci Alquran}

Alquran adalah petunjuk-Nya yang dipelajari akan membantu menemukan nilainilai yang dapat dijadikan pedoman bagi penyelesaian berbagai problem hidup dan apabila dihayati serta diamalkan akan menjadikan pikiran, rasa, dan karsa mengarah kepada realitas keimanan yang dibutuhkan bagi stabilitas dan ketentraman hidup pribadi dan masyarakat. Dalam pemahaman tentang Alquran terhadap ayat-ayat tertentu bisa berbeda-beda berdasarkan perbedaan tingkat perkembangan pengetahuan mereka berdasarkan perbedaan kepekaan hati nurani mereka.

Tafsir Alquran menggambarkan kerendahan hati bahwa pemahaman atau penafsiran kita atas suatu ayat tertentu masih 
mungkin salah dan ayat itu dalam dirinya sendiri adalah sesuatu yang mutlak karena berasal dari Tuhan sehingga dalam menerapkan suatu ayat dalam situasi tertentu semuanya menjadi relatif karena tergantung dari pemahaman manusia itu sendiri. Penggambaran keimanan atau keyakinan terhadap kitan suci Alquran dapat dilihat pada puisi yang berjudul "Janganlah Kiranya Ditutupkan itu Cahaya Quran".

\section{Ada cahaya.}

Cahaya itu datang sebagai garis lurus,

Ketika matahari memecah lazuardi dan layar malam yang hitam telah digulung kembali, cahaya itu tetap menerangi negeri kita.

\section{Cahaya yang datang dari Quran, yaitu Quran yang bukan cuma perhiasan tapi Quran bacaan, Quran yang bukan cuma bacaan tapi Quran yang maknanya diresapkan Quran yang bukan cuma maknanya diresapkan tapi Quran yang isinya deras mengalir memasuki dan menyuburkan seluruh jalur kehidupan.}

Kami mengaku

kami zalim terhadap diri sendiri, kami banyak cacat

Itu dan ini,

Tapi janganlah ditutupkan

Cahaya Quran bagi kami semua.

Wahai Yang Maha Pemberi Cahaya, wahai Yang Maha Pemurah dan Bijaksana. Janganlah biarkan Quran Di rumah kami Cuma jadi pelengkap perabotan,

(Ismail, 2013:263-271)

Penggalan bait puisi di atas bermakna akidah iman kepada kitab suci Alquran.
Penyair menjelaskan bahwa begitu pentingnya Alquran dalam kehidupan sehari-hari sebagai petunjuk untuk menjadi pribadi muslim yang beriman dan dirindukan oleh Allah SWT. kelak. Penggunaan bahasa kiasan, yaitu personifikasi, ditandai dengan diksi 'cahaya' yang dimaksud oleh penyair adalah Alquran, membuat puisi berjudul "Janganlah Kiranya Ditutupkan itu Cahaya Quran" mengajak pembaca untuk selalu membaca dan memaknai setiap arti untuk dijadikan pedoman dalam menyikapi hidup dan kehidupan. Hal ini bertujuan untuk mencapai keseimbangan hidup dunia dan akhirat, maka diharapkan petunjuk yang sudah dibuatkan oleh Allah SWT. dalam Alquran dengan bahasa yang indah tidak hanya sekadar hiasan lemari buku saja tetapi lebih dari sahabat sejati yang bisa dibawa dan dibaca kapan dan di mana saja. Hal ini yang diharapkan oleh penyair kepada diri sendiri dan juga pembaca karya puisi karena dalam doa yang ditorehkan pada puisi tersebut, penyair mengajak untuk selalu jadikan Alquran sebagai pedoman hidup.

\section{e. Iman Kepada Takdir Allah}

Takdir atau Qadha dan Qadar adalah ketentuan Allah bagi manusia yang menunjukkan ke-Mahakuasaan Allah dalam menentukan nasib manusia. Allah Mahakuasa untuk menentukan apa saja yang dikehendakiNya. Oleh sebab itu, setiap muslim harus yakin dan percaya bahwa Allah Maha Kuasa dan Mahamengetahui tentang nasib seluruh makhluk. Allah sudah menentukan nasib setiap makhluknya, tetapi tidak seorang pun makhluk yang mengetahui nasibnya. Allah 
Maha Kuasa dan Maha Berkehendak. Jika Allah menghendaki maka Allah Maha Kuasa untuk mengubah nasib makhluk-Nya, jika ia berusaha untuk mengubahnya. Hal ini digambarkan oleh Taufik Ismail lewat puisi yang berjudul "Membaca Tanda-Tanda" dalam bait berikut ini.

Kita saksikan udara Aceh penuh mendung abu-abu warnanya

Kita saksikan burung-burung kecil tak lagi berkicau pagi hari

Kita saksikan puluhan mayat, ratusan mayat, ribuan mayat

Kita saksikan puing, lumpur, potongan kayu, besi, bangkai

Kendaraan

Jeritan anak yang kehilangan ayah Jeritan ayah yang kehilangan anak Jeritan istri yang kematian suami Jeritan suami yang kematian isteri Jeritan keluarga yang kehilangan semuanya Jeritan bangsa yang kehabisan segalanya

Telah kami rasakan gempa di daratan Telah kami deritakan gempa di lautan Telah kami alami gunung api Telah kami alam banjir tsunami besarbesaran

Telah kami rasakan dadakan

berpuluh ribu kematia

Beri kami kemampuan

membaca tanda-tanda

Apa yang dapat kami sumbangkan, kami sumbangkan

Apa yang dapat kami lakukan, kami lakukan Apa yang dapat kami doakan, kami doakan

Luar biasa bertumpuk dosa kolektif kami Kurniai kami keampunan Kurniai kami kemampuan Membaca tanda-tanda

(Ismail, 2013:137-143)

Puisi di atas menjelaskan akidah iman kepada Qadha dan Qadar, yaitu semua ciptaan Allah akan diuji dengan mendatangkan bencana alam, seperti gempa, tanah longsor, kelaparan, kematian massal, dan lain-lain. Sebagai makhluk ciptaan Allah, manusia hanya bisa menjalankan skenario yang sudah ditentukan Allah SWT. serta berserah diri kepada-Nya atas setiap musibah yang diberikan. Hal ini juga sudah dijelaskan Allah SWT. dalam Alquran QS. Asy Syu'ara tentang tanda-tanda Qadha dan Qadar. Semua bencana yang terjadi adalah teguran untuk hamba yang beriman sehingga meningkatkan keimanan dan ketakwaannya serta hukuman bagi hamba yang tidak beriman, tidak menjalankan perintah dan menjauhi laranganNya. Hal inilah yang diungkapkan oleh penyair lewat puisinya dengan bentuk puisi naratif dan berkabar serta gaya bahasa yang indah, penyair ingin menyampaikan kepada pembaca untuk selalu mengingat Allah SWT.

Selain itu penggambaran iman kepada takdir Allah ini dapat dilihat pada puisi berjudul "Sajadah Panjang" dalam bait berikut.

\section{Ada sajadah panjang terbentang \\ Dari kaki buaian \\ Sampai ke tepi kuburan hamba \\ Kuburan hamba bila mati.}

(Ismail, 2013:445)

Puisi di atas, menunjukkan bahwa akidah iman kepada Qadha dan Qadar, yaitu semua manusia akan kembali kepada sang pencipta. Hidup ini adalah perjalanan kembali ke asal, yaitu kematian. Kita semua berasal dari Allah akan kembali kepada-Nya. Perjuangan pula kembali itu tidak akan sesat dengan selalu mengingat Allah dan mendapat keridaan-Nya. 
Hidup ini berpangkal dari sesuatu dan berujung kepada sesuatu, yaitu Allah SWT., pencipta alam semesta dan pemberi kehidupan serta yang mengakhiri segala kehidupan di muka bumi.

\section{f. Iman Kepada Hari Kiamat}

Iman kepada hari kiamat adalah meyakini datangnya hari akhir. Iman kepada hari kiamat merupakan rukun iman yang kelima. Dengan iman kepada hari akhir akan menjadikan seseorang akan selalu bersikap hati-hati dalam melakukan perbuatannya. Perbuatan tersebut senantiasa mengingat kehidupan di akhirat sehingga terciptalah antara kehidupan dunia dan akhirat. Berikut ini bait yang menunjukkan keimanan pada hari akhir terdapat pada puisi berjudul "Ketika El Maut Disembelih", yaitu dalam bait berikut.

\section{Ketika hari pengadilan semesta selesai dinyatakan \\ Ketika keputusan terakhir telah dijatuhkan \\ Ketika sejarah manusia dijagat raya telah ditutup dengan resmi \\ Meliputi berapa ribu milyar tahunnya Meliputi berapa trilyun manusianya Membuka panorama yang dahsyatnya luar biasa.}

(Ismail, 2013:295)

Bait puisi di atas bermakna akidah iman kepada hari kiamat. Melalui puisinya penyair merepresentasikan keyakinan bahwa kedatangan hari akhir itu pasti ada. Tidak ada lagi kehidupan di dunia melainkan kematian yang hakiki, yaitu kehidupan yang kekal di surga atau akhirat. Manusia yang dikategorikan masuk surga adalah manusia yang semasa hidupnya melakukan ibadah kepada Allah SWT dengan penuh keikhlasan, bukan sekadar mencari kenikmatan duniawi saja. Begitu pula sebaliknya, manusia yang masuk neraka adalah manusia yang hanya sekadar menikmati hidup di dunia saja tanpa beribadah yang ikhlas kepada Allah SWT. sebagai Tuhan Sang Pencipta dan Sang Agung.

Selain itu iman kepada hari akhir juga terdapat pada puisi berjudul "Seberat-Berat Penghinaan"

\section{Tapi bila datang hari kiamat nanti \\ Tak akan ada tempat melarikan diri \\ Tak ada tempat untuk bersembunyi lagi \\ Tak ada alasan begitu dan begini}

\section{(Ismail, 2015:313)}

Penggalan bait puisi di atas bermakna akidah iman kepada hari kiamat. Penyair mengajak pembaca untuk meyakini bahwa hari kiamat itu pasti ada dan akan datang sesuai dengan yang sudah dijanjikan oleh Allah SWT. Hari akhir/kiamat adalah hari ketika semua umat dikumpulkan untuk mempertanggungjawabkan semua perbuatan yang sudah dilakukan semasa hidup di dunia. Penyair menyampaikan kepada pembaca untuk selalu berbuat baik, adil, jujur sesama manusia, dan makhluk hidup lainnya, karena tidak ada tempat pelarian jika hari kiamat sudah didatangkan oleh Allah SWT. Selain itu, penyair juga mengajak pembaca melalui puisi tersebut untuk tidak saling menghina, saling menghujat, saling mencaci-maki sesama makhluk ciptaan Allah SWT. Karena semua perbuatan tercela tersebut akan dibalas oleh Allah dengan tempat 
yang paling ditakuti dan siksaan yang paling mengerikan, yaitu siksaan api neraka yang tiada satu orang pun dapat merasakan dan membayangkan pedihnya azab api neraka tersebut.

Hal lain membuktikan iman kepada hari akhir juga terdapat pada puisi berjudul "Malam Seribu Bulan" yaitu dalam bait berikut.

\section{Ketika Sangkakala Angkasa.}

(Ismail, 2013:233)

Bait puisi di atas mengambarkan bahwa akidah iman kepada hari kiamat terdapat pada kutipan "Ketika Sangkakala Angkasa”. Penyair mengajak pembaca untuk meyakini bahwa datangnya hari akhir/kiamat ditandai dengan suara tiupan terompet yang ditiup oleh Malaikat Israfil. Dengan adanya penggalan puisi tersebut secara tidak langsung penyair meyampaikan kepada pembaca untuk tidak berleha-leha di dunia, karena hidup di dunia tidak akan kekal, serta jika sangkakala sudah ditiupkan maka tidak akan ada lagi waktu untuk bertaubat dan berbuat baik sesama manusia lagi. Hal ini juga dijelaskan dalam QS. Az-Zumar:68 dan QS. Yasin:51.

\section{Akhlak}

Akhlak merupakan pola tingkah laku yang baik maupun buruk. Jika perilaku yang melekat itu baik, maka disebut akhlak yang baik atau akhlak mahmudah (yang meliputi tidak putus asa, berbakti pada orang tua, bertaubat, dan berpendirian). Jika perilaku yang melekat itu buruk, maka disebut akhlak yang buruk atau akhlak mazmumah (yang meliputi zhalim).

\section{a. Tidak Putus Asa}

Tidak putus asa merupakan bentuk tingkah laku yang baik dan terpuji (akhlak mahmudah). Akhlak dalam nilai-nilai Islam mengajarkan supaya tidak berputus asa dalam menghadapi hidup sehingga ketika tertimpa musibah dan permasalahan dihadapi dengan penuh tawakal dan kesabaran. Putus asa menunjukkan bahwa seseorang itu kurang bersabar dalam menghadapi ujian hidup sedangkan dalam nilai Islam memberikan anjuran agar selalu bersabar dalam menerima musibah karena Allah menyukai orang-orang yang sabar dan tidak putus asa. Ajaran untuk bersabar dan tidak putus asa terdapat pada puisi berjudul "Kerja Besar dan Berat, Kini Menanti”, yaitu dalam bait berikut.

Kerja keras bersama, kinilah saatnya

Keras bekerja, keras bekerja, keras bekerja

Dan tak henti pula berdoa

Memohonkan keampunanNya

Mohon kekuatan untuk seluruh bangsa.

(Ismail, 2013:167)

Bait puisi di atas mengambarkan bahwa akhlak berupa tidak putus asa. Manusia dalam perjuangan jangan putus asa terhadap apa yang dicita-citakannya. Di luar kekuasaan masih ada kekuasaan Allah karena yang menentukan nasib manusia yaitu Allah SWT. Dalam hal ini menunjukkan potensi fitrah yang dimiliki manusia kepada iman. Manusia terlahir 
membawa potensi fitrah, yaitu nilai-nilai keimanan terhadap Sang Pencipta. Nilai fitrah ini akan selalu muncul dalam keyakinan manusia, sekalipun manusia terlahir di kalangan orang yang tidak beriman dan tidak beragama yang lurus, atau hidup di tempat yang terasing dan tidak masuk ajaran tentang ketuhanan, tetapi naluri pengakuan akan adanya Tuhan yang selalu ada, hanya saja tuntutan itu ada yang teraktual dengan baik dan ada yang tidak. Di samping itu, nilai-nilai kebenaran iman tidak akan ditemukan tanpa adanya petunjuk dan ajaran Tuhan.

\section{b. Berbakti kepada Orang Tua}

Berbakti kepada orang tua merupakan bentuk aspek akhlak yang sangat terpuji. Berbakti kepada orang tua merupakan sikap kepatuhan seorang anak terhadap orang tuanya yang sangat dihargai dan dihormatinya karena kasih sayang terhadap anaknya yang telah membesarkan dan merawatnya hingga dewasa. Bentuk perilaku inilah yang dianjurkan dalam aspek akhlak dalam nilai-nilai Islam. Hal ini juga ditekankan dalam oleh Taufik Ismail lewat puisi yang berjudul "Guru" dalam bait berikut.

Guru yang harus disebut pertama sekali

Adalah ibuku sendiri

Guru yang dalam satu nafas harus pula disebut pertama sekali

Adalah ayahku sendiri.

(Ismail, 2013:115)

Kutipan puisi di atas menjelaskan nilai akhlak berbakti kepada orang tua. Penyair mengungkapkan cara-cara berbakti kepada kedua orang tua, yaitu di antaranya dengan cara menghormati dan mengakui bahwa orang yang pertama kali untuk diingat dan sebut adalah Bapak dan Ibu kita. Penggunaan gaya bahasa metafora yaitu 'guru' menjelaskan pemaknaan berbakti kepada orang tua dengan cara seorang anak wajib mengingat jasa-jasa yang sudah diberikan oleh orang tua, walau jasa tersebut tidak dapat dibayar dengan apa pun. Dengan cara mengingat dan menyebutkan nama orang tua di setiap doa sudah merupakan kegiatan membalas jasa jariah orang tua yang tidak pernah mengharap imbalan apa pun kepada anaknya.

\section{c. Bertaubat}

Bertaubat merupakan bentuk aspek akhlak yang terpuji. Kesadaran seseorang setelah melakukan perbuatan yang salah dalam pengakuan dosa-dosanya menyebabkan munculnya perbuatan taubat. Aspek akhlak dalam nilai Islam mengajarkan untuk bertaubat, mengakui segala kesalahan yang kita perbuat, dan berjanji serta berusaha tidak akan mengulangi kesalahan yang sama. Hal ini menunjukkan bahwa manusia tidak luput dari salah dan manusia memiliki kelemahan yang jauh dari kesempurnaan. Ajaran untuk bertaubat digambarkan oleh Taufik Ismail lewat puisi yang berjudul "Nasihat-Nasihat Orang Kecil Orang Tua Pada Anaknya Yang Berangkat Dewasa" yang dapat dilihat pada bait berikut. 
Jika adalah yang tidak bisa dijual-belikan Ialah yang bernama keyakinan Jika adalah yang harus kau tumbangkan Ialah segala pohon-pohon kezaliman Jika adalah orang yang harus kau agungkan

Ialah hanya Rasul Tuhan

Jika adalah kesempatan memilih mati Ialah syaid di jalan Ilahi.

(Ismail, 2013:15)

Penggalan bait puisi di atas menjelaskan nilai akhlak bertaubat. Penyair menyampaikan pesan dakwahnya yang merupakan representasi nilai religi, yaitu menghimbau bagi pembaca untuk segera bertaubat di jalan Allah ketika berada di jalan yang menyesatkan, seperti bermaksiat, berbuat zalim, tidak adil, dan jujur. Dengan mengingat Allah SWT serta ajaran Rasulullah senantiasa membawa pribadi pembaca menjadi seorang muslim yang tangguh dan bertakwa. Di tengah perkembangan zaman era digital atau modern ini, masyarakat sudah banyak terlena akan nikmat duniawi semata, sehingga melupakan ajaran agama Islam yang hakiki. Maka dari itu, penyair selalu menghimbau para pembaca untuk bertaubat dalam setiap penggalan bait-bait puisi yang ditulisnya.

\section{d. Berpendirian}

Berpendirian merupakan sikap teguh dan tidak berpaling terhadap apa yang sudah diyakini seseorang. Hal ini menunjukkan kuatnya keimanan seseorang dalam keyakinannya. Aspek akhlak dalam nilai-nilai Islam mengajarkan supaya memperkuat keimanan dengan yakin sepenuhnya dengan rukun iman sehinggga tidak akan berpaling dari perintah dan kewajiban dari-Nya. Bentuk sikap berpendirian dapat dilihat pada puisi berjudul "Ada Anak Bertanya Pada Ibunya" dalam bait berikut.

\section{Pasti mama akan tutup mulut ketika kawan- kawan mama bergosip \\ Pasti mama akan tutup telinga ketika kawan -kawan mama \\ Bergunjing \\ Tidak tertarik lagi mengikuti kebiasaan tidak terpuji itu.}

(Ismail, 2013:93)

Penggalan bait puisi di atas menjelaskan nilai akhlak berpendirian. Penyair menjelaskan kepada pembaca bahwa sikap berpendirian perlu diterapkan dalam kehidupan sehari-hari agar terhindar dari pengaruh perbuatan tercela, seperti bergunjing. Dalam ajaran agama Islam bergunjing adalah perbuatan yang sangat dibenci dan dilaknat oleh Allah SWT. Hal ini terdapat dalam QS Al-Hujurat ayat 11. Selain terhindar dari perbuatan tercela, akhlak berpendirian juga melindungi diri dari sikap yang ganda atau gampang terbawa arus pergaulan yang di zaman sekarang sudah dipengaruhi oleh pergaulan bebas. Dengan menerapkan akhlak berbpendirian seseorang juga akan menjadi pribadi yang disiplin dan berwibawa serta dihargai oleh siapa saja.

\section{e. Zalim}

Zalim merupakan bentuk aspek akhlak buruk yang disebut dengan akhlak mazmumah. Zalim merupakan perbuatan yang melewati batas kebenaran dan cenderung kepada kebatilan. Orang-orang yang zalim 
adalah orang-orang yang menghambat seseorang untuk memperoleh haknya. Hal ini terdapat dalam puisi berjudul "Bagaimana Ini, Hati Saya Tertutup mati", yakni zalim seorang pemimpin/penguasa pada suatu negara/negeri terutama pada rakyat sendiri yang dapat dilihat dalam bait sebagai berikut.

\section{Saya harus mengaku bahwa mata rohani saya sudah buta \\ Bahwa hati saya, seperti batu kali, sudah tertutup mati \\ Padahal hampir tiap hari saya \\ Melihat tayangan di layar kaca \\ Tentang anak-anak pengungsi yang luar \\ biasa menderita \\ Banyak yang yatim, yang piatu, tanpa orang tua}

Semua tanpa nafkah karena tak ada kerja.

(Ismail, 2013:191)

Penggalan bait puisi di atas bermakna akhlak zalim yang ditandai dengan kutipan / saya harus mengakui bahwa mata rohani saya sudah buta. Hal ini menjelaskan seseorang yang memiliki kelebihan dalam bentuk harta dan takhta, tetapi tidak memiliki hati nurani untuk membantu sesama atau masyarakat yang tertimpa musibah. Puisi yang ditulis penyair menggambarkan ketamakan seseorang yang tidak mau memberikan hak kepada yang membutuhkan. Hal ini berkaitan dengan akhlak yang dimiliki oleh beberapa oknum aparat negara yang tidak peduli akan nasib rakyatnya. Penyair tidak menyebutkan langsung nama oknum tersebut, tetapi hal ini sudah sering terjadi hingga pemerintahan sekarang. Sebagian oknum hanya ingin memperkaya diri, keluarga, dan partai yang mereka dukung tanpa mempedulikan nasib masyarakat golongan bawah. Namun, dalam hal ini penyair mengajak kepada pembaca terutama kepada aparat oknum yang dimaksud untuk segera insaf dan mengasihi sesama agar keadilan merata dirasakan di negara Indonesia.

Berdasarkan hasil analisis data, nilai-nilai Islam dalam kumpulan puisi Debu di Atas Debu: Kumpulan Puisi Dwi-Bahasa karya Taufik Ismail ini dapat dibahas bahwa kumpulan puisi tersebut sarat akan nilai-nilai Islam yang dapat dijadikan pedoman bagi pembaca. Selain itu, nilai-nilai Islam yang disampaikan oleh Taufik Ismail pada setiap puisinya juga merupakan pengalaman penyair sendiri berdasarkan latar belakang sosial yang dipengaruhi oleh kebudayaan lokal. Hal ini disebabkan melalui puisi-puisi yang ditulis, Taufik Ismail ingin berkabar. Pernyataan Taufik ini juga diungkap pada kalimat berikut, "Saya mau menyampaikan berita, mendalang dan berkisah lewat puisi saya, kepada pendengar dan pembaca saya" (Hamzah, 2010). Selain itu, pernyataan Taufik juga diulas oleh (Khadijah, 2011) yaitu "Agar komunikatif, puisi harus punya substansi sebagai kabar, mesti cerdas dan musikal sedap didengar di sana di sini puisinya bisa juga jenaka".

Taufik Ismail, penyair yang dikenal luas sebagai tokoh sastrawan Angkatan '66 ini lahir di Bukittinggi, 25 Juni 1935 dan dibesarkan di Pekalongan. Dalam Tempo, Mei 2008 disebutkan bahwa ia pernah menggunakan 
nama samaran, yaitu Nur Fadjar. Ayahnya adalah seorang ulama Muhammadiyah terkemuka, K.H. Abdul Gaffar Ismail, dan ibunya, Tinur Muhammad Nur. Dengan latar belakang keluarga seperti itulah Taufik dikenal sebagai penyair yang bernapaskan keagamaan. Selain itu, Taufik juga seorang kolumnis dan berulang kali menulis lirik lagu untuk kelompok Bimbo.

Berdasarkan analisis data nilai-nilai Islam dan biografi Taufik Ismail dapat disimpulkan bahwa kumpulan puisi Debu di Atas Debu karya Taufik Ismail merupakan representasi ajaran-ajaran Islam yang disampaikan oleh penyair berdasarkan fakta ajaran Islam pada setiap bait-bait puisi. Hal ini dibuktikan pada salah satu bait Laut dan gunung bertasbih memuja Tuhan// Awan dan sungai berzikir mengagungkan Tuhan// Pohon-pohon bertasbih memuja Tuhan//. Kutipan tersebut mengajak pembaca bahwa semua benda mati tunduk dan memuja Tuhan tanpa alasan apa pun, begitu juga dengan manusia dengan segala kelemahan dan kekurangan tetap harus tunduk dan memuja Tuhan sebagai Sang Pencipta yang penuh kasih sayang. Puisi-puisi yang ditulis memiliki pengaruh yang kuat akan seni pedalangan ketika Taufik Ismail bermukim di Yogyakarta dan seni kaba ketika ia pindah ke Bukittinggi. Hal ini membuktikan pengaruh kebudayaan lokal dalam setiap puisi-puisi karangan Taufik Ismail. Berdasarkan seni pedalangan dan kaba beberapa puisi Taufik dijadikan lirik lagu relegius oleh kelompok musik Bimbo.

\section{Kesimpulan}

Kumpulan puisi Debu di Atas Debu: Kumpulan Puisi Dwi-Bahasa karya Taufik Ismail sarat dengan nilai-nilai Islam. Setiap nilai tersebut merupakan representasi ajaran agama Islam berdasarkan kitab Alquran. Nilai-nilai Islam yang terdapat dalam kumpulan puisi tersebut terungkap melalui penataan bunyi, pilihan kata, penggunaan gaya bahasa, pencitraan, latar belakang realitas pemerintahan orde baru, sikap penyair terhadap realitas yang ditampilkan dan sikap penyair terhadap pembaca. Adapun nilai religi yang terdapat dalam kumpulan puisi karya Taufik Ismail adalah pertama, akidah meliputi (1) iman kepada Allah terdapat pada satu di antara beberapa puisi yang berjudul "Cerita Seorang Anak Yatim Piatu Selepas Pesta Ulang Tahun Tetangganya" yang bermakna seorang anak kecil yang baru saja merayakan ulang tahun meyakini bahwa yang menentukan umur dan nasibnya adalah Allah SWT. yang sudah menciptakannya, bukan jumlah lilin pada kue atau pada setiap tanggal kelahirannya diperingati. (2) iman kepada Malaikat terdapat pada satu dari beberapa puisi yang berjudul "Ternyata Kau Shalat Tidak Sendirian" bermakna walaupun seseorang melaksanakan salat sendirian, salatnya tidak akan batal karena ada malaikat yang selalu setia menemani dari penjuru arah mana pun. Berdasarkan hal itu, penyair menyampaikan kepada pembaca, dengan keadaan bagaimana pun, salat lima waktu tetap harus dilaksanakan oleh seorang muslim di mana saja sesuai dengan waktu salat, baik sendirian atau secara berjamaah. (3) iman kepada rasul terdapat pada satu di antara beberapa puisi yang berjudul "Anakku Bertanya 
Tentang Rasul" bermakna Seorang ibu meyakini bahwa Rasul adalah nabi yang mulia pilihan Allah SWT. Hal ini dijelaskan dengan rinci kepada anaknya ketika sang anak bertanya pada seorang ibu tersebut.(4) iman kepada Takdir terdapat pada puisi berjudul "Sajadah Panjang" puisi tersebut menunjukkan bahwa akidah iman kepada Qadha dan Qadar, yaitu semua manusia akan kembali kepada sang pencipta. (5) iman kepada Hari Kiamat terdapat pada judul puisi "Malam Seribu Bulan" bermakna penyair mengajak pembaca untuk meyakini datangnya hari akhir/kiamat ditandai dengan suara tiupan terompet yang ditiup oleh Malaikat Israfil. Ibadah yang terkadung dalam kumpulan puisi ialah bermunajat, berdakwah, berdoa. Kedua, akhlak dalam kumpulan puisi meliputi akhlak baik (mahmudah) yakni tidak berputus asa, berbakti pada orang tua, bertaubat, berpendirian, sedangkan akhlak buruk (mazmumah) meliputi zalim.

Kepengaran Taufik Ismail dipengaruhi oleh kebudayaan lokal sehingga menginspirasi Taufik dalam menciptakan karya puisi-puisinya. Terlahir di Kota Bukittinggi, dan dibesarkan di Kota Yogyakarta membawa efek terhadap kepenga-rangan Taufik karena Kota Bukittinggi dan Yogyakarta dikenal dengan kota sentral pendidikan agama Islam, sehingga unsur budaya, adat, dan agama yang dianut oleh masyarakat Minangkabau dan masyarakat Yogya menginspirasi setiap karya yang ditulis oleh Taufik. Dalam bakaba Taufik ingin menyentuh perasaan, laju, menghilir, dan komunikatif bagi pembaca karyanya. Serta unsur gaya bahasa dalam penyampaian bakaba terdapat pada karyanya menjadikan puisi tersebut menjadi indah dan menarik.

\section{Daftar Pustaka}

Azami, A. (n.d.). Penerjemahan sebagai Penafsiran: Studi Akurasi dan Gaya Bahasa Puisi Taufik Ismail Debu di Atas Debu. Jakarta: Skripsi UIN Jakarta.

Endraswara, Suwardi. 2011a. Metodologi Penelitian Sosiologi Sastra. Yogyakarta: Caps.

Faridoni, S. (2013). "Ya Profetik Puisi Taufik Ismail". Ibda': Jurnal Kebudayaan Islam, 11, No. 2, 173-190.

Geertz, Clifford. 1973, 2000 (edition). The Interpretation of Cultures. New York: Perseus.

Hamzah, M. (2010). “Melacak Jejak Pemikiran Taufik Ismail Ihwal Pendidikan Lewat Puisi-Puisinya Taufik Ismail Thought Trail of Education Through his Poems Abstract". Deiksis, Vol.02 No., 178-196.

Hall, Stuart. 1997. Culture, the Media and the Ideological Effect. London: Mass Communication \& Society.

Ismail, Taufik. 2013. Debu di Atas Debu: Kumpulan Puisi Dwi-Bahasa. Jakarta: Majalah Sastra Horison.

Khadijah. (2011). "Nilai Pendidikan Aqidah dalam Kumpulan Puisi Malu (Aku) Jadi Orang Indonesia Karya Taufik Ismail". Jurnal Visipena, Vol. II No.2, 1-9.

Krippendorff, K. H. (2004). Content Analysis: An Introduction to Its Methodology. London: Sage Publication.

Mahmud, Kusman K. 2011. Pengarang dalam Karya Telaah Terbatas Atas Kehadiran Diri Pramoedya Ananta Toer dalam Fiksifiksinya Satu Tinjauan Estetika Sastra. Bandung: Skripsi Unpad Jatinangor.

Nurbanah, Naim. 2003. Nilai-nilai Islam dalam Kumpulan Puisi "Nyanyi Sunyi" Karya Amir Hamzah. Semarang: Skripsi UNNES.

Muslim Nurdin, dkk. 1995. Moral dan Kognisi Islam. Bandung: CV. Alfabeta.

Putri, F. M. (2015). Gaya Bahasa Perulangan dalam Kumpulan Puisi Debu di Atas Debu Karya Taufik Ismail. Sumatera Barat: Skripsi STKIP PGRI Sumbar.

Suryana, Toto, dkk. 1996. Pendidikan Agama Islam Untuk Perguruan Tinggi. Bandung: Tiga Mutiara.

Ratna, I Nyoman Kutha. 2010. Teori Metode dan Teknik Penelitian Sastra. Yogyakarta: Pustaka Belajar. 